Revue belge de géographie

3-4 | 2008

Formatting Europe - Mapping a Continent

\title{
Unknown Europe: The mapping of the Northern countries by Olaus Magnus in 1539
}

Europe inconnue : la cartographie des pays nordiques par Olaus Magnus en 1539

\section{Leena Miekkavaara}

\section{(2) OpenEdition}

1 Journals

\section{Electronic version}

URL: http://journals.openedition.org/belgeo/7677

DOI: $10.4000 /$ belgeo.7677

ISSN: 2294-9135

Publisher:

National Committee of Geography of Belgium, Société Royale Belge de Géographie

\section{Printed version}

Date of publication: 31 December 2008

Number of pages: 307-324

ISSN: 1377-2368

\section{Electronic reference}

Leena Miekkavaara, "Unknown Europe: The mapping of the Northern countries by Olaus Magnus in 1539", Belgeo [Online], 3-4 | 2008, Online since 22 May 2013, connection on 05 February 2021. URL: http://journals.openedition.org/belgeo/7677 ; DOl: https://doi.org/10.4000/belgeo.7677

This text was automatically generated on 5 February 2021.

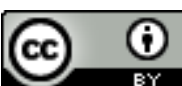

Belgeo est mis à disposition selon les termes de la licence Creative Commons Attribution 4.0 International. 


\section{Unknown Europe: The mapping of the Northern countries by Olaus Magnus in 1539}

Europe inconnue : la cartographie des pays nordiques par Olaus Magnus en 1539

Leena Miekkavaara

1 At the beginning of the $16^{\text {th }}$ century the Northern countries were a very unknown region to most people in southern Europe. The information about the North was based on the descriptions written in the Antiquity and Medieval times, and depicted on few maps. The region was often described as an island in a nameless northern sea, or as an east-to-west "peninsula" resembling the shape of an oak leaf. Before Olaus Magnus's map, the most important earliest maps of the Nordic countries - that have survived to our days - were in addition to the map published in 1532 by the Bavarian Jacob Ziegler - (figure 1) those that appeared in the numerous printed "Ptolemy Editions". They were based on the map compiled in 1427 by the first Nordic cartographer, the Dane Claudius Clavus, and improved by the German Nicolaus Germanus (figure 2). The cartographic representation of the North was, however, quite faulty and far from reality.

2 Olaus Magnus wanted to change this inaccurate view with a map he had started compiling already in 1527. 
Figure 1. Map by Jacob Ziegler 1532 (The National Library of Finland).

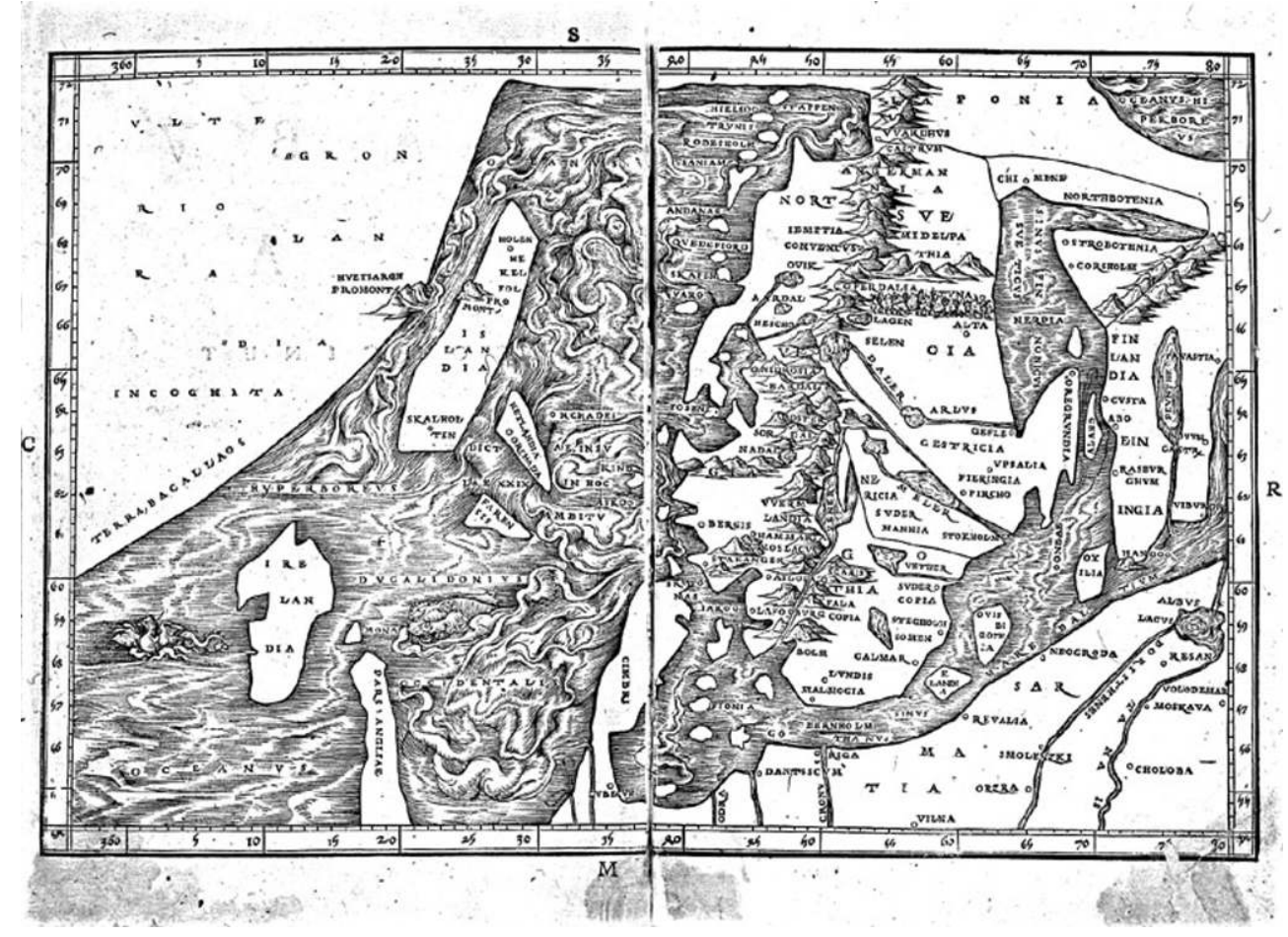

Figure 2. Map based on Claudius Clavus's map of the Northern countries, 1427, printed in the Ptolemy edition Ulm 1482 (The National Library of Finland).

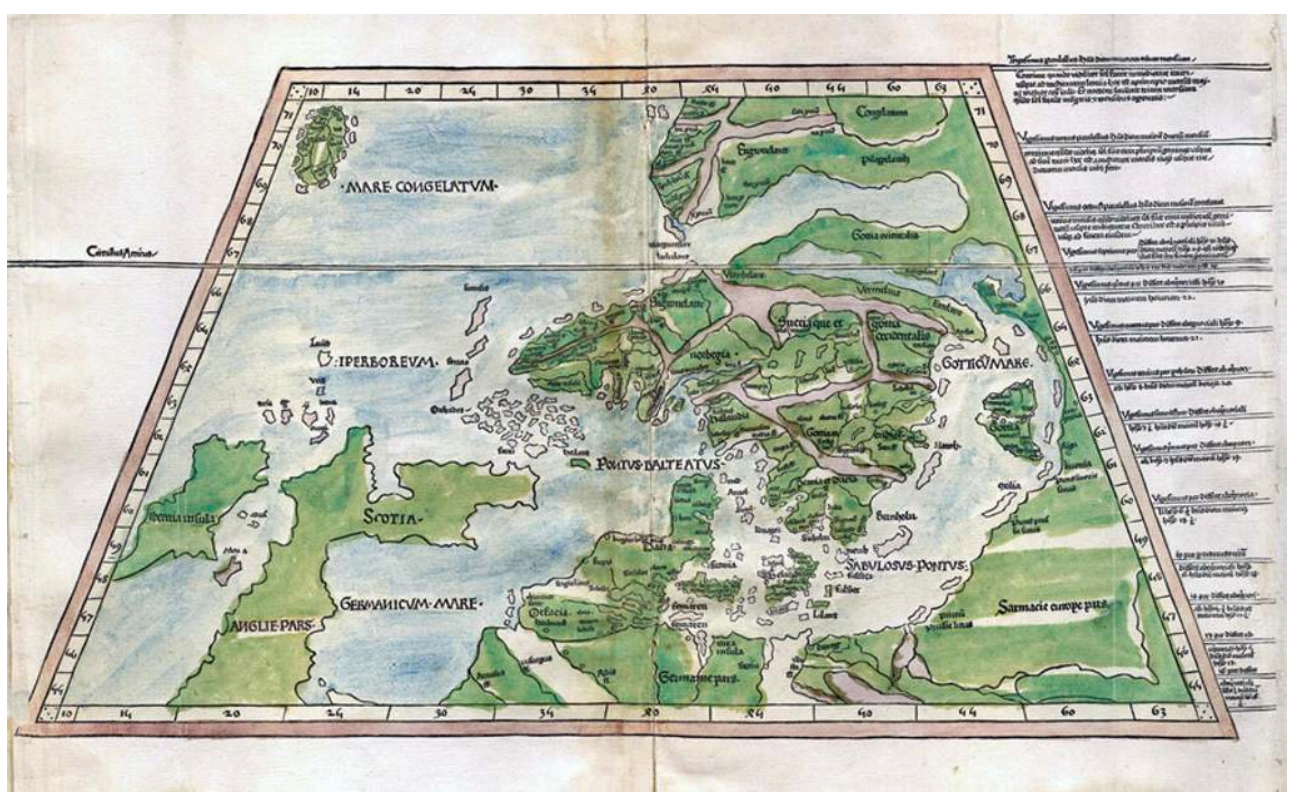

\section{The man and his map}

3 Olaus Magnus (Linköping, Sweden 1490 - Rome 1557) ${ }^{1}$ was a highly educated Swedish scholar and the last - though only nominal - Catholic archbishop of Uppsala. Because of his duties for the Church and the King, he had travelled widely both in the North 1518-1519 in Sweden, Norway and northern Finland, and later also in central and 
southern Europe - Italy, Germany, The Netherlands, Poland and the Hanseatic towns of Hamburg, Lübeck, Bremen and Danzig. He had studied in Germany for seven years and lived for several years abroad, mostly in Danzig and in Italy. He was a true cosmopolitan of his time (figure 3).

Figure 3. "Olaus Magnus on his way to Norway".

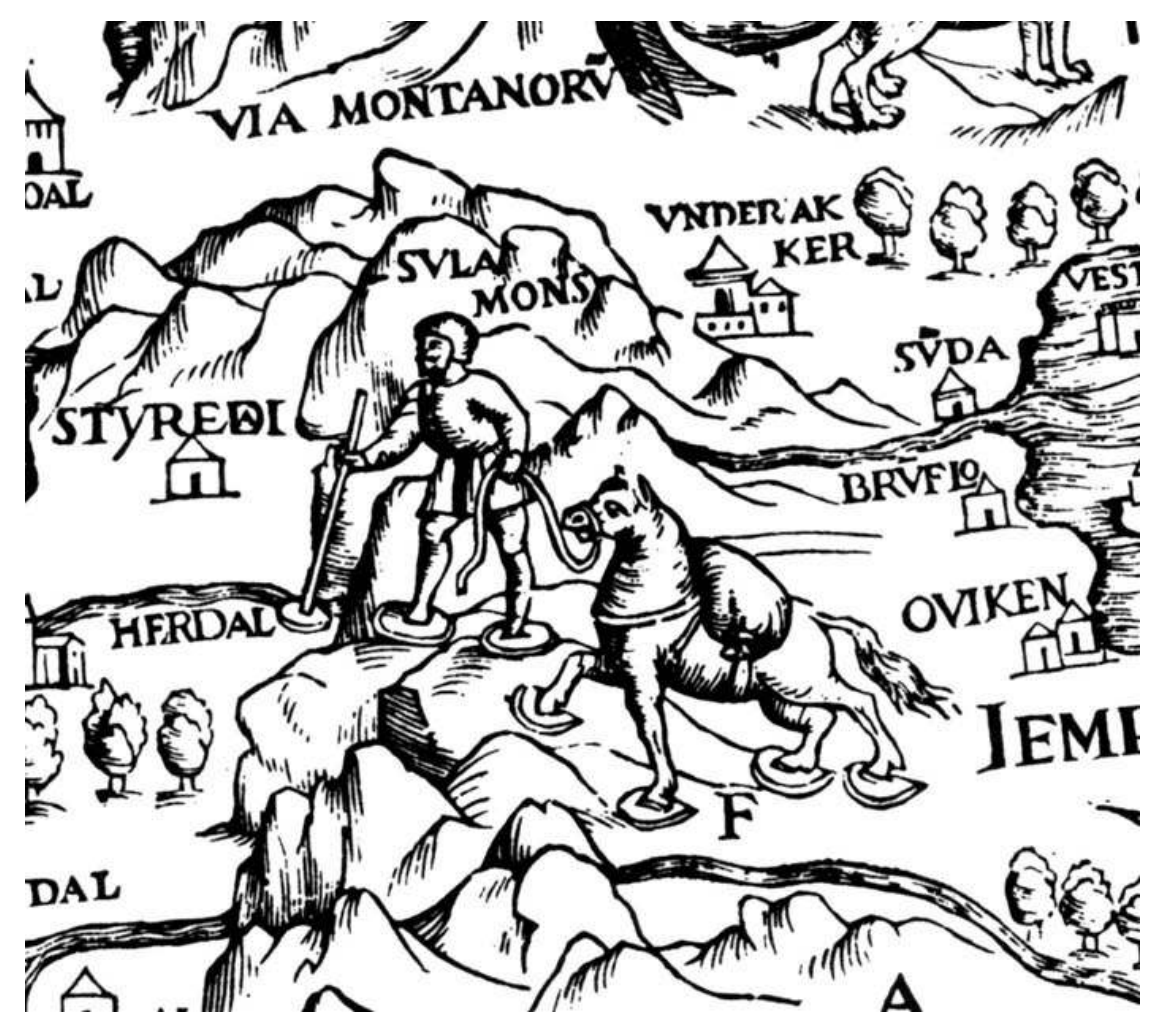

4 In addition to the literature of his own time, he knew the texts of the Classic and Medieval writers - Pytheas, Pliny the Elder, Jordanes, Tacitus, Adam of Bremen, Saxo Grammaticus, etc. - and he knew many of the maps of his predecessors. He had many connections with several scientists and scholars as well as mapmakers. During his travels in the Northern countries, he - as a man of the Renaissance - had made observations and very carefully recorded everything he had seen and heard about people, places and nature. Thus he had good qualifications - although he was not a real cartographer - to compile his map, which he named Carta marina, as we know it today, but which he himself always later referred to as Carta gothica.

Olaus Magnus started compiling his map in Danzig, where he had with his brother Johannes gone into exile, because as devout Catholics they could not accept the Reformation as realised in Sweden-Finland by the King Gustavus Vasa. After twelve years' work the map was finished in Venice. On the $11^{\text {th }}$ March 1539 Pope Paul III gave Olaus Magnus the right to publish his map and guaranteed him the privilege for ten years to the map and all the future commentaries in the form of books intended to explain the map. The map was printed by Giovanni Thomaso (Tomasso) and it was for sale in the shop of Thomas de Rubis near the Rialto Bridge in Venice (Ahlenius, 1895, 59; Richter, 1967, 35, 38; Sheet $G$ of the map).

6 In spite of compass roses, loxodromes, some anchorages and of its name Carta marina et descriptio septemtrionalium terrarum ac mirabilium rerum in eis commentarum delicentissime 
elaborata anno dni 1539 Veneciis liberalitate Rmi D. Ieronimi Qvirini: Patriarche Venetiae - [A marine map and description of the Northern Countries and their marvels, most carefully drawn up at Venice in the year 1539 through the generous assistance of the Most Honourable Lord and Patriarch Hieronimo Quirino] - the map was not a sea chart. Olaus Magnus obviously copied the name Carta marina from the world maps of Martin Waldseemüller and Lorenz Fries from the years 1516 and 1525, respectively. "The generous assistance" referred to in the legend of the map meant that Hieronimo Quirino paid the expenses of its engraving and publishing amounting to 440 ducats, and offered to the Magnus brothers his hospitality during their stay in Venice.

7 The Carta marina was one of the largest printed maps of its time. It was cut on nine wooden blocks and measured $125 \times 170 \mathrm{~cm}$ (figure 4). The map contained numerous illustrations and about 900 place names and other geographical and cartographical facts. The craftsman, or craftsmen who cut them in wood, are still unknown. At the time also Dutch and German wood-engravers were working in Venice (Lynam, 1949, 19; Richter, 1967, 39).

8 Nobody knows, either, how many copies of the Carta marina were printed. The estimations have greatly varied from a few copies to a wide circulation, from about twenty to some hundreds.(Balzamo, 2005, 56; Ehrensvärd, 2006, 66; Lynam, 1949, 35; Richter, 1967, 38). Presumably their number was limited because the map disappeared in the 1570s. Since then it was known for more than 300 years through its meticulous copy, a reduced two-plate version engraved in copper, published in Rome in 1572 by Antonio Lafreri.

Figure 4. Carta marina by Olaus Magnus 1539 (Facsimile of the original at the Uppsala University Library by Karttakeskus 1993).

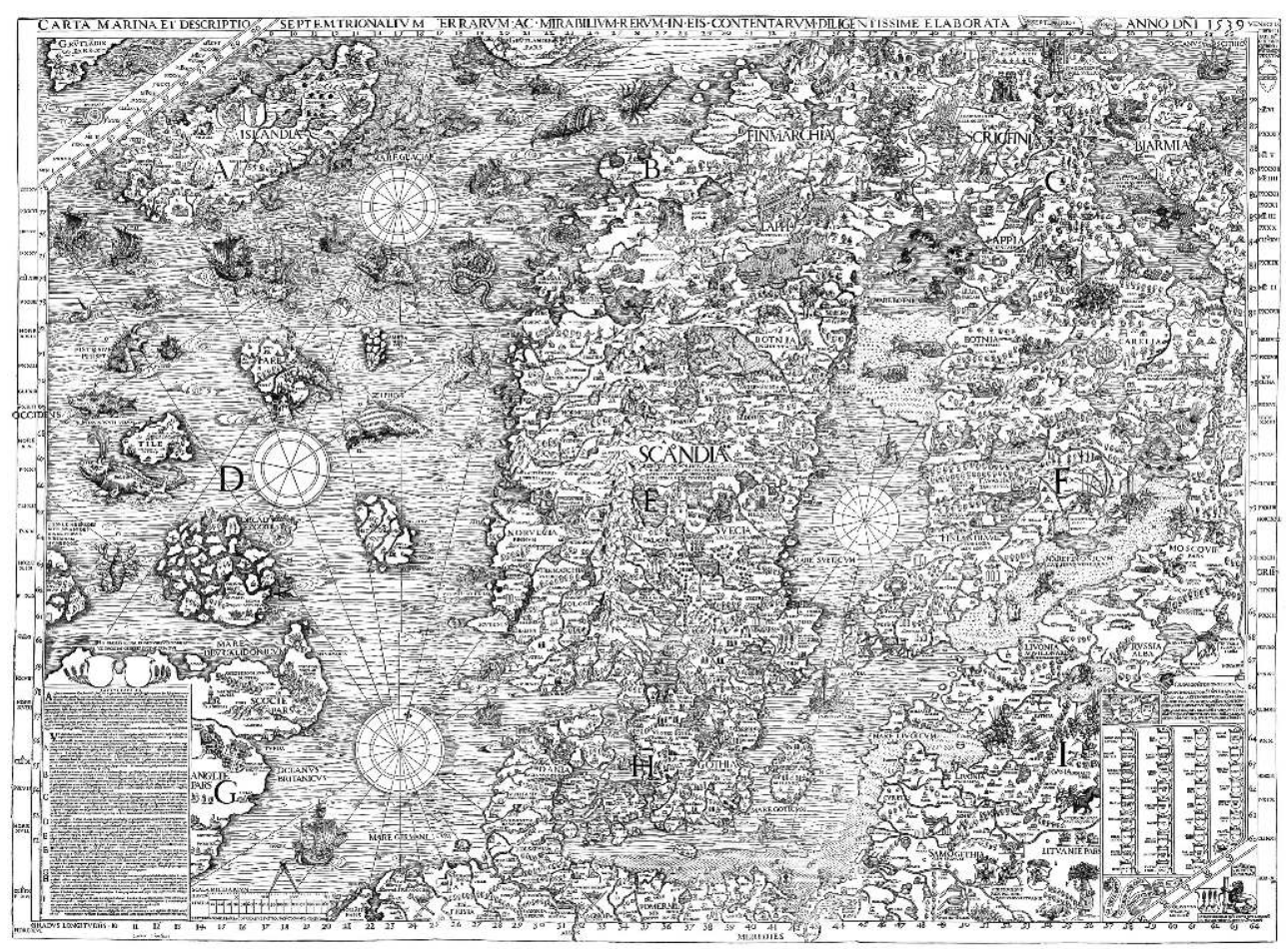

Today only two original copies of the Carta marina are known. The first one was found in Munich in 1886 at the Bayerische Staatsbibliothek, where it still exists, and the other 
- which the Uppsala University Library managed to obtain - turned up in Switzerland in 1962.

With his map, Olaus Magnus wanted to rectify the faulty representation of the earlier especially the widespread Ptolemaic - maps, and he also wanted to show the Catholic Church the extent of the area which had been lost to Lutheranism. But, above all, he wanted to describe his dear native country as accurately and impressively as possible. As a patriot, who after 1524 never returned to his homeland Sweden again, he emphasized its ascendancy over other countries as the original home of the Goths. (Ahlenius, 1895, 61-62; Grape, 1970, 97-98; Richter, 1967, 25, 44-45) (figure 5).

Figure 5. In this table Olaus Magnus gave the names of the nations which, according to the ancient authors, had had their origin on the island of Scandia and spread all over the world.

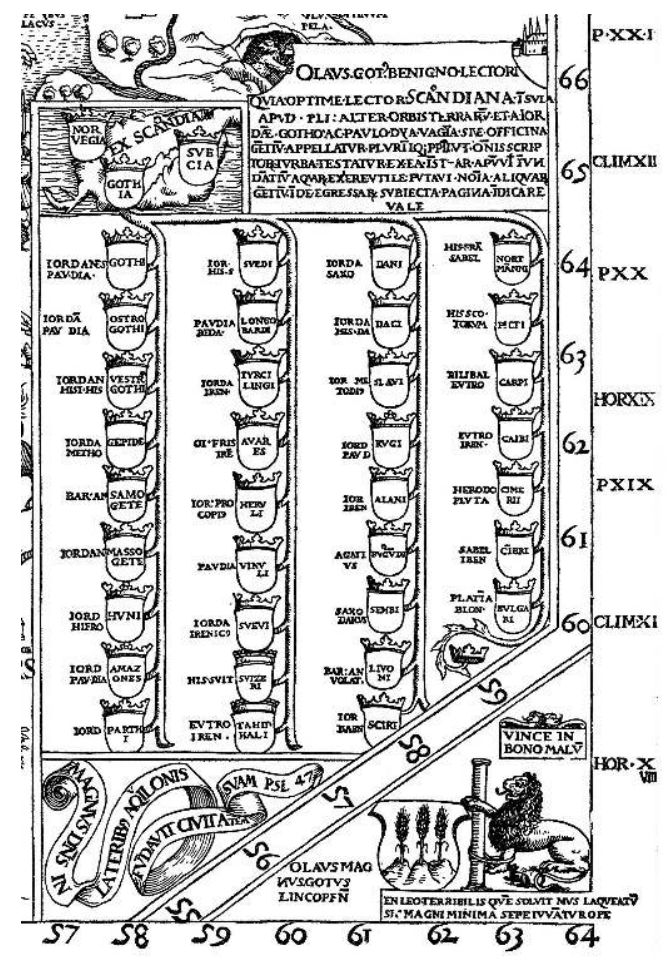

In the lower right-hand corner there are the signature of Olaus Magnus, the coat of arms of the family Magnus and an allegorical picture based on Aesop's story with the text « The mouse releases the terrible lion, so the works of the little ones often help the big ones ».The lion has been seen to stand for the Scandinavian peoples and the mouse for Olaus Magnus, their interpreter and geographical « liberator ».

Olaus Magnus understood that his great, profusely illustrated map might be difficult for "an ignorant reader" to understand. That is why he marked the nine sheets of his map with large letters from A to I, and 89 - instead of 101 on the map - small letters within the area of each large letter to indicate matters briefly referred to in the Latin commentary in the lower left-hand corner of the map. (Miekkavaara, 2007, 299). He also wrote in 1539 two more extensive - i.e. booklets with 16 pages and 101 small letters - vernacular commentaries in Italian and German which were slightly different in content. This was because the Italian Opera breve [A short treatise], published in June, was destined for the southern European and the German Ain kurze Auslegung und 
Verklerung der neuuen Mappen [A short interpretation and explanation of the new map], published in July, to the northern European nations.

Olaus Magnus told, in both the Italian and German commentaries "that he wanted to give a description about the marvellous things, both on land and at sea, in the old Gothic realm and the other cold northern countries beyond the north sea, mare Germanico, until now unknown to both Greek and Latin authors, and about which up to now it has not been clearly written in the world". In his commentaries Olaus Magnus often mentioned that he would later write even more about these marvels. This he did in 1555, when he published an extensive, more than 800-paged work on the history of the northern peoples, Historia de gentibus septentrionalibus printed in Rome. The work contained 22 books, which were divided into 778 chapters and illustrated with 481 woodcuts, of which 20 were duplicates. During the years 1555-1669 twenty-two editions of this popular work - complete or abbreviated - were published in six languages: Latin, Italian, French, German, Dutch and English (Ahlenius, 1895, 125-133; Bratt, 1953, 268). The work contained much of the same material as the Carta marina and 124 of its illustrations. (Granlund, 1951, 594-595).

\section{The Portrayer of past and present}

Through the illustrations and their explanations, Olaus Magnus wanted to convey the conditions of the North to the more southernly inhabitants of Europe.

He described northern life during the $16^{\text {th }}$ century in a fascinating way and with an enthusiastic patriotism. The wealth of his information was enormous. He described almost everything concerning man and nature: geography, history, ethnography, means of livelihood, politics, various natural phenomena etc. In many cases the motifs of the pictures - animals, fishes, birds, scenes of hunting, boats, minerals, habits of people, especially their ability to get along with the winter, cold, snow, ice, etc. - did not illustrate only those areas where they were placed on the map, but were common to the North in general. (Miekkavaara \& Koistinen, 1993, 4; Miekkavaara, 1994, 9) (figures 6 and 7). 
Figures 6 and 7. These two pictures, describing the life in snow and on the frozen sea, were the only illustrations in the Opera breve and Ain kurze Auslegung in 1539. The figures of the hunters showing that even women hunted - were depicted separately on the Carta marina. Both pictures were included exactly one to one in the History in 1555.
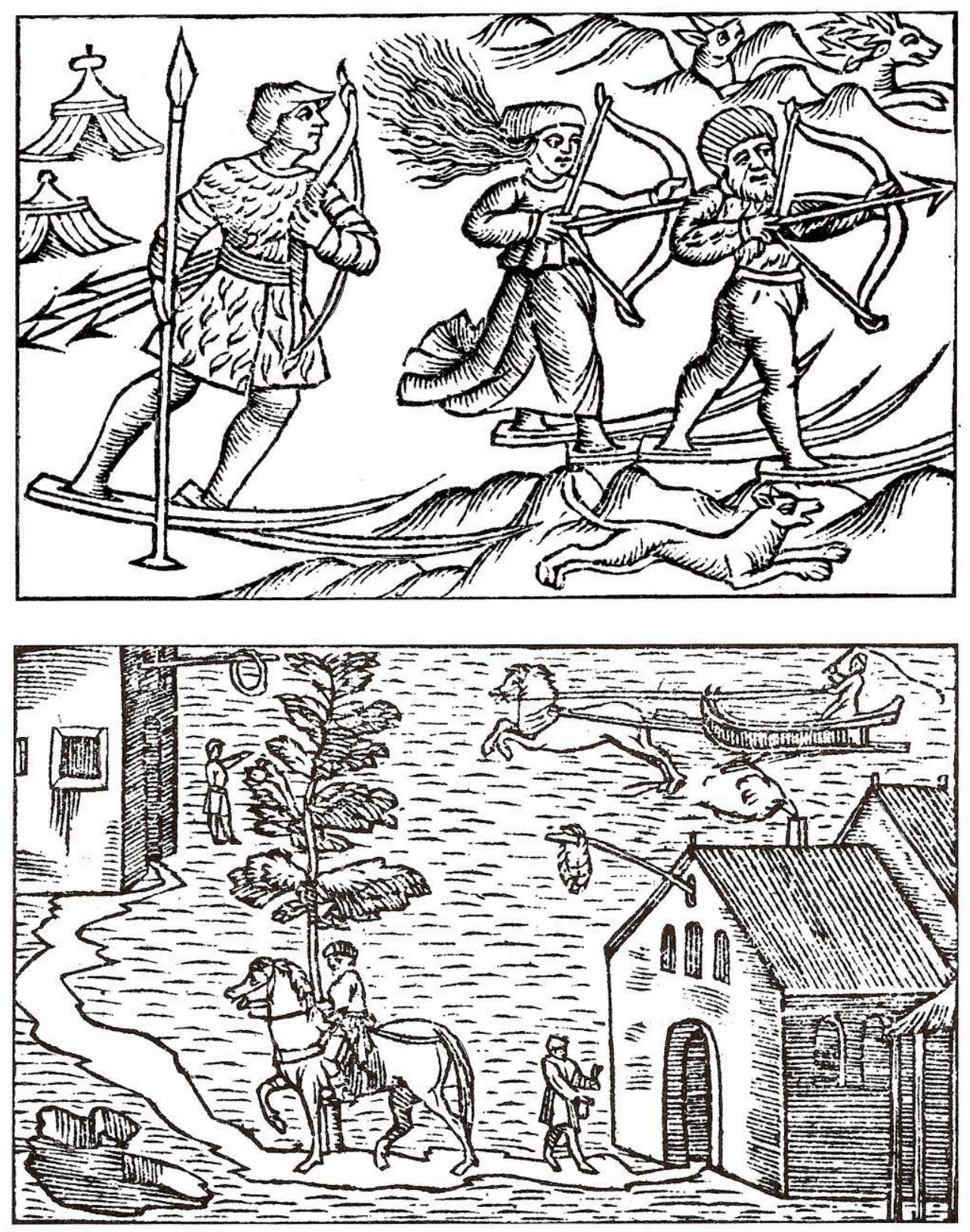

16 Some of his information was fiction, however, although Olaus Magnus assured his readers that everything he described was true, seen by his own eyes and experienced and researched by himself. But one has to be aware that the attitudes and reality were different compared to our days. Olaus Magnus had researched numerous earlier authors and taken "their facts" and described them on this map - as seen by his own eyes, but described, for instance, by Saxo Grammaticus or somebody else. Olaus Magnus saw the past realistically. (Granlund, 1946, 129).

17 Olaus Magnus was not the first who filled the map with illustrations. The medieval mappamundis and portolans were rich in pictures, but olaus Magnus was the first to depict the relics of Antiquity on the map (Granlund, 1951, 586) (figure 8). He told about 
runic writings, historical events, battles fought etc. On the other hand, he also described the phenomena of his own time and everyday life, including people in their day-to-day chores as well (figure 9). So the content of the map was a mixture of ancient and new.

Olaus Magnus prepared his pictures during a long period of time. The greatest part of them was based on his own observations, and many of them were even drawn by himself. Some pictures can be traced to famous painters like Hans Holbein the younger, and to well-known works like Orlando Furioso, Dyalogus creaturarum and Hortus sanitatis. (Foote, 1996, xliii; Granlund, 1951, 585, 595).

Figure 8. Almost in the middle of the map Olaus Magnus quoted Pliny's and Procopius's texts telling us that Scandia was a whole world in itself, ten times as large as Britain and containing thirteen kingdoms. Under the text King Gustavus, most mighty king of Swedes and Goths enthroned in regal robes, and the coat of arms of Sweden.

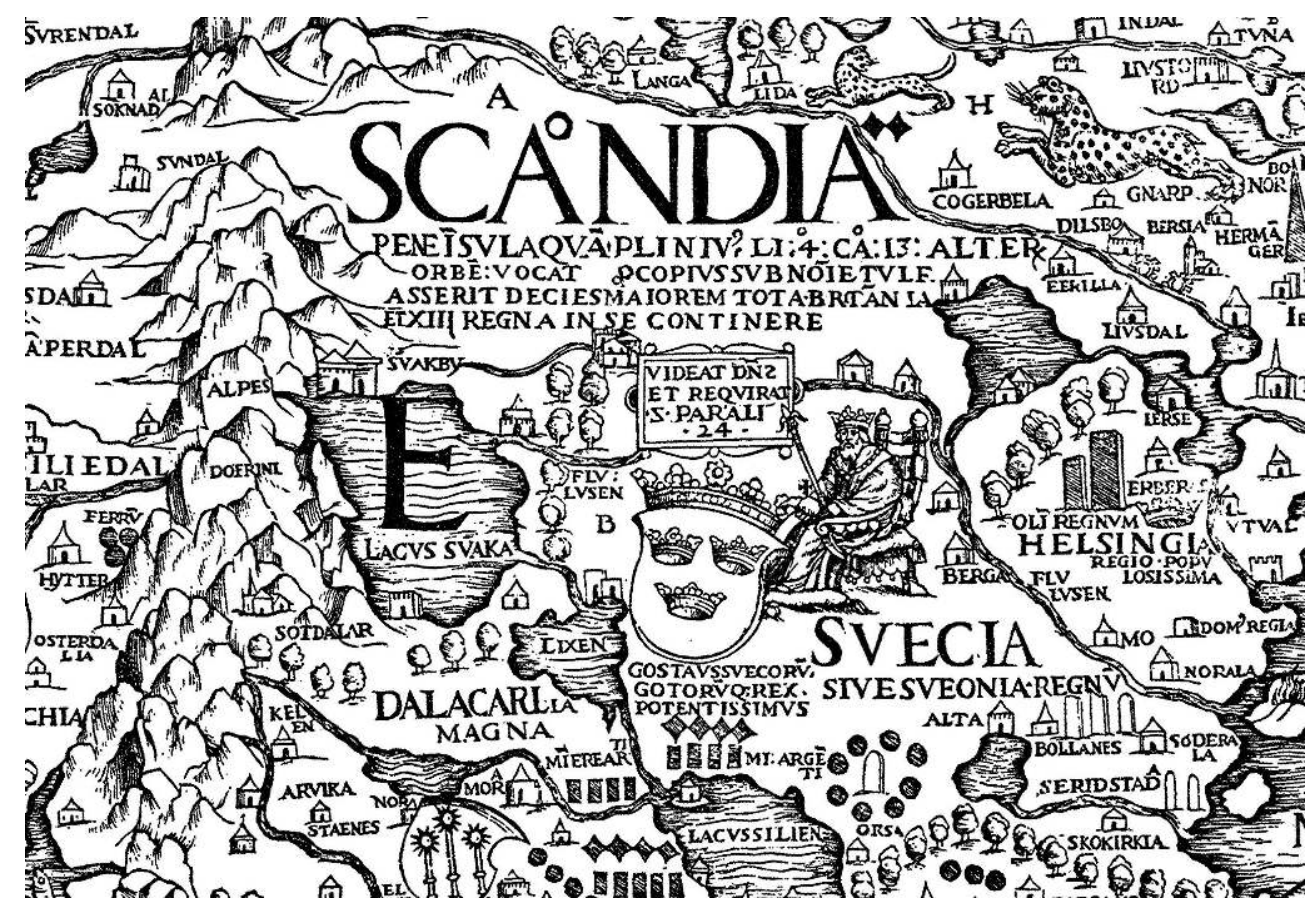

\section{Known, but still unknown...}

When the Carta marina was published, it attracted much attention. Even today the map draws the researchers' interest and has even caused debates. The last word has not yet been said about many matters concerning Olaus Magnus and his map, e.g. about these three recently come up questions: Which were Olaus Magnus's sources while sketching out the geographical shape of the region; how to interpret his strange graduation system; and why aren't the two known original copies of the map quite identical?

\section{About sources}

The sources Olaus Magnus used in order to be able to outline his map have been the subject of a lot of discussion. It has been proved that he himself left no information on his sources. In his surviving correspondence there are only a few individual notes of 
the map but nothing about the technical methods. Therefore the almost only possibility for finding answers is the use of available comparative material, i.e. older and contemporary maps, charts and sailing directions of northern regions (Richter, 1939, 104; Richter, 1967, 46-47), and trying to find out the relations with various mapmakers. This method, however, has often produced results coloured by the researchers' own assumptions.

It has been generally believed that it was Olaus Magnus who made this epoch-making map, because he knew all kinds of circumstances in the North and prepared his map and its commentaries with enthusiasm (Richter, 1939,112), and also because he was a cosmopolitan of his time who had colleagues and friends all over Europe. Certainly it is possible that he had models, but these have not been unambiguously proved.

Before the Carta marina several maps depicting the northern regions are known to have been compiled - e.g. F. Monachus, 1526; Jan de Beeldsnijer, 1526; L. Algoet, 1530; B. Wapowski, 1533 - but they have disappeared having left almost no traces. (Granlund, 1951, 585; Karrow, 1993, 35).

From the surviving maps, it has been detected that e.g. on the terrestrial globe prepared in 1535/37 by Gemma Frisius together with the young Gerard Mercator and on the world map in 1538 by Gerard Mercator the shape of the northern regions is reminiscent of Olaus Magnus's, but the sources they used are unknown. (Granlund, 1951, 583; Richter, 1967, 77-79).

Over the years different assumptions for the model of the Carta marina have been presented. One of the latest is a rather bold proposition, that Olaus Magnus copied his map from the now lost map prepared by the Flemish Liévin Algoet in 1530 (Ehrensvärd $2006,63)$. The argumentation has been based on the correspondence and acquaintanceship between several parties, and the map of Algoet published by Gerard de Jode in 1562 and $1570^{2}$. The level of the real skills of Algoet as a cartographer has not been proved, (Ginsberg, 2006, 85; Karrow, 1993, 35) neither has de Jode's part in adding information to the map. The motifs of the illustrations on the map and especially the letterpress of 23 lines at the right-hand lower corner of the 1562 version speak for Olaus Magnus, who had already prepared this map for three years before the publication of Algoet's map. Naturally it is possible that Algoet and Olaus Magnus, who moved in the same scientific circles, have exchanged their information. On the other hand, some value may be given to Olaus Magnus's own statements in order to evaluate his predecessors. After having finished his map in 1539 Olaus Magnus wrote in its commentary Ain kurze Auslegung, that many pious and learned men have wished to prepare a work like this but in spite of their good will they have not been able to get it finished because of their inexperience (Ain kurze Auslegung 1539, Ao).

Anyway - whatever the truth is - the question about who was the first is still without an answer. 
Figure 9. Day-to-day chores: a woman milking a reindeer, a man hunting a capercaillie and men fishing on the ice.

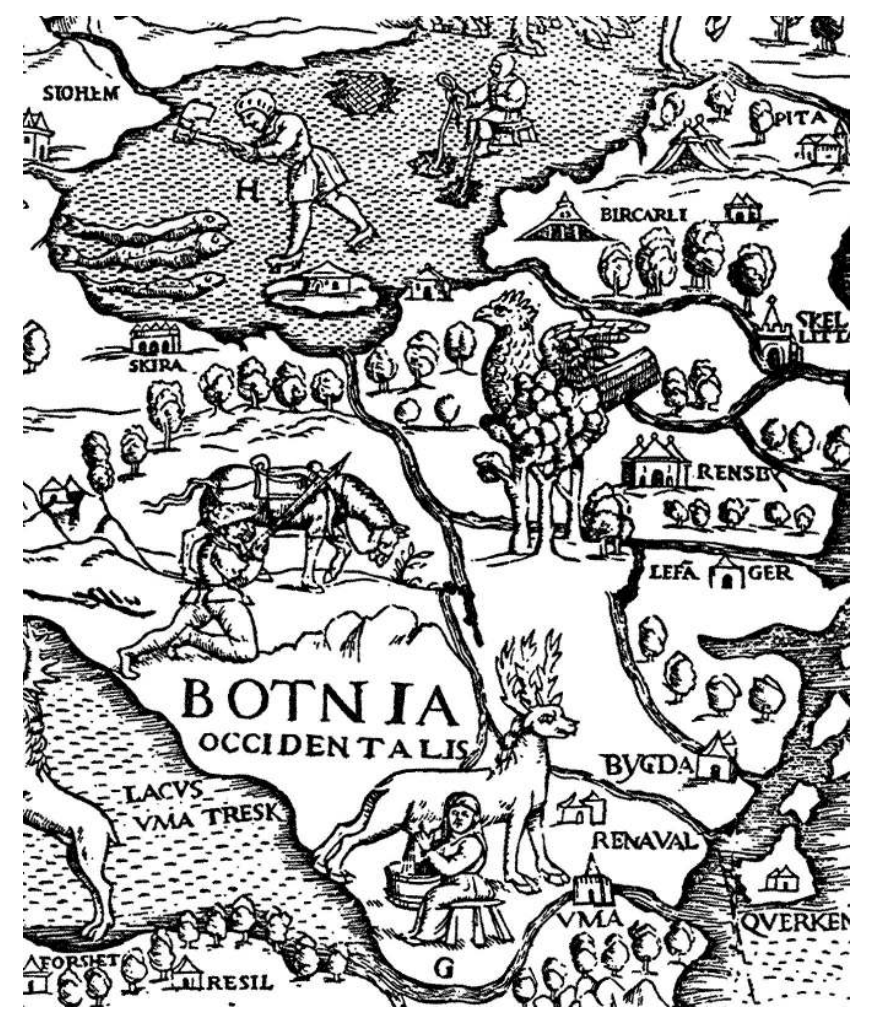

\section{About the graduation}

It has been said that Olaus Magnus was more a geographer and ethnographer than a cartographer. Some writers have even doubted his skills in mathematics and astronomy, although it has been stated that these subjects had belonged to his syllabus (Balzamo 2005, 58; Lynam 1949, 5; Richter 1967, 63). Olaus Magnus himself gave an impression that he knew how to prepare a map. He e.g. explained the differences between Italian, German and Gothic/Swedish miles, and stated that the meridians can be confusing, too, since some place the prime meridian at the Canary Islands (Isole fortunate), others in Ireland (Ibernia). (Opera breve and Ain kurze Auslegung 1539, G).

It has been generally stated that the projection of the map is a modified Marinus, which is relatively unsuitable for maps depicting areas in high latitudes, and that the prime meridian passes off the west coast of Ireland. (Ahlenius, 1895, 71; Lynam, 1949, 5; Richter, 1967, 90). The latitudes and longitudes are marked in the margins, together with Hore, i.e. the length of the longest days in hours. The letter P connected with Roman numerals refers to the parallels, which are 34 in all. They mark the limits of the zones, indicated by the letters CLI (clima), in which the length of the day varies within the range of two hours. In the upper left corner the Hore are replaced by MES (menses) to indicate the length of the longest day in months.

This strange graduation system has greatly puzzled the scholars. (Ahlenius 1895, 80; Crone \& George/Granlund 1952,82; Richter 1967, 85-88) (figure 10). Especially the interpretation of Olaus Magnus's 90 latitude - i.e. the question whether he placed the northern part of Scandinavia up to the North Pole - has divided them (figure 11). The most heated discussion happened at the end of the 1940s, when two British scholars 
showed a calculation with a figure to prove that Olaus Magnus's 90 degree was actually 661/2, the Arctic Circle (Grone \& George, 1949, 199-200; Crone, 1951, 43; Richter, 1967, 88). A Swedish expert didn't accept that at all. He even presumed that Olaus Magnus probably regraduated his map after completing it. (Granlund, 1950, 43; 1951, 585).

Olaus Magnus explained his system by writing that "I am sure that every educated person with common sense understands what the longitudes and latitudes are. I know I have treated the wide countries very briefly, but I do hope that nobody criticises me before he has produced something better. (Ain kurze Auslegung, Ao). I am sure my work will be approved of by men of learning and accepted with favour and gratitude" (Opera breve, Ao).

Today his work has been approved, but the question how he prepared it, is still without an answer.

Figure 10. The first efforts to explain the strange graduation by Olaus Magnus. (K.Ahlenius, 1895, 80 and 435).

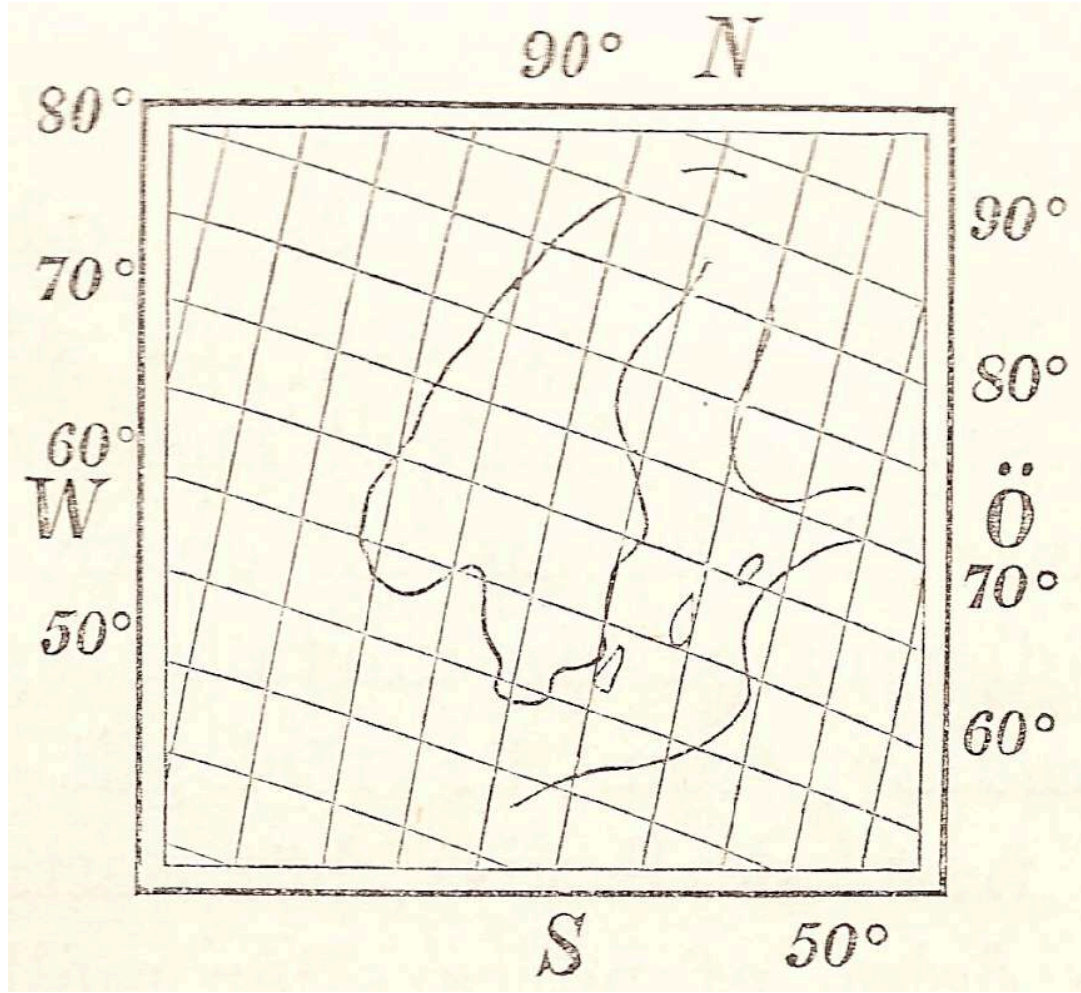




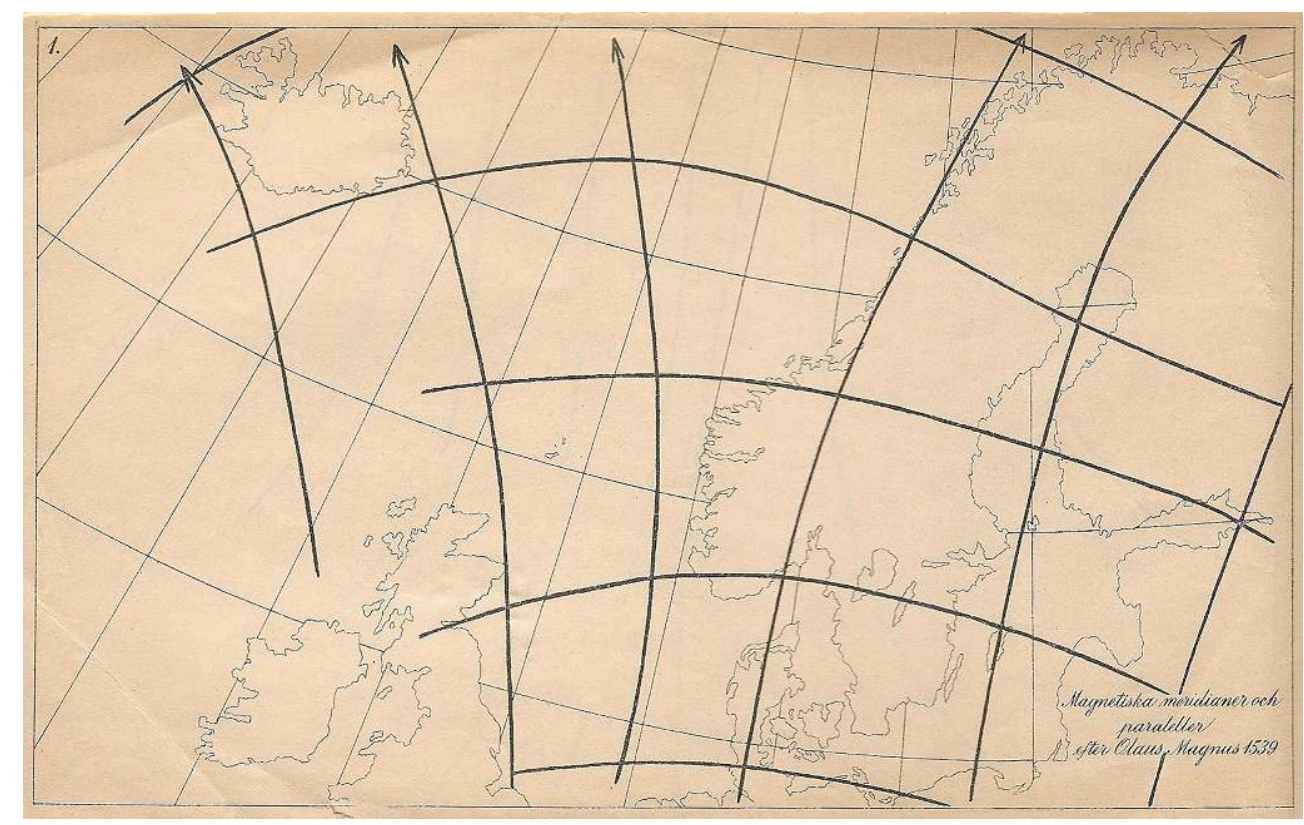

Figure 11. Beside the text " the realm of Sweden extends to here " stands Starkather - an ancient fist-fighter, as a guardian, here naturally Swedish! Olaus Magnus stated that the magnetic island was thirty miles under the pole. The North Pole he placed clearly outside of his map.

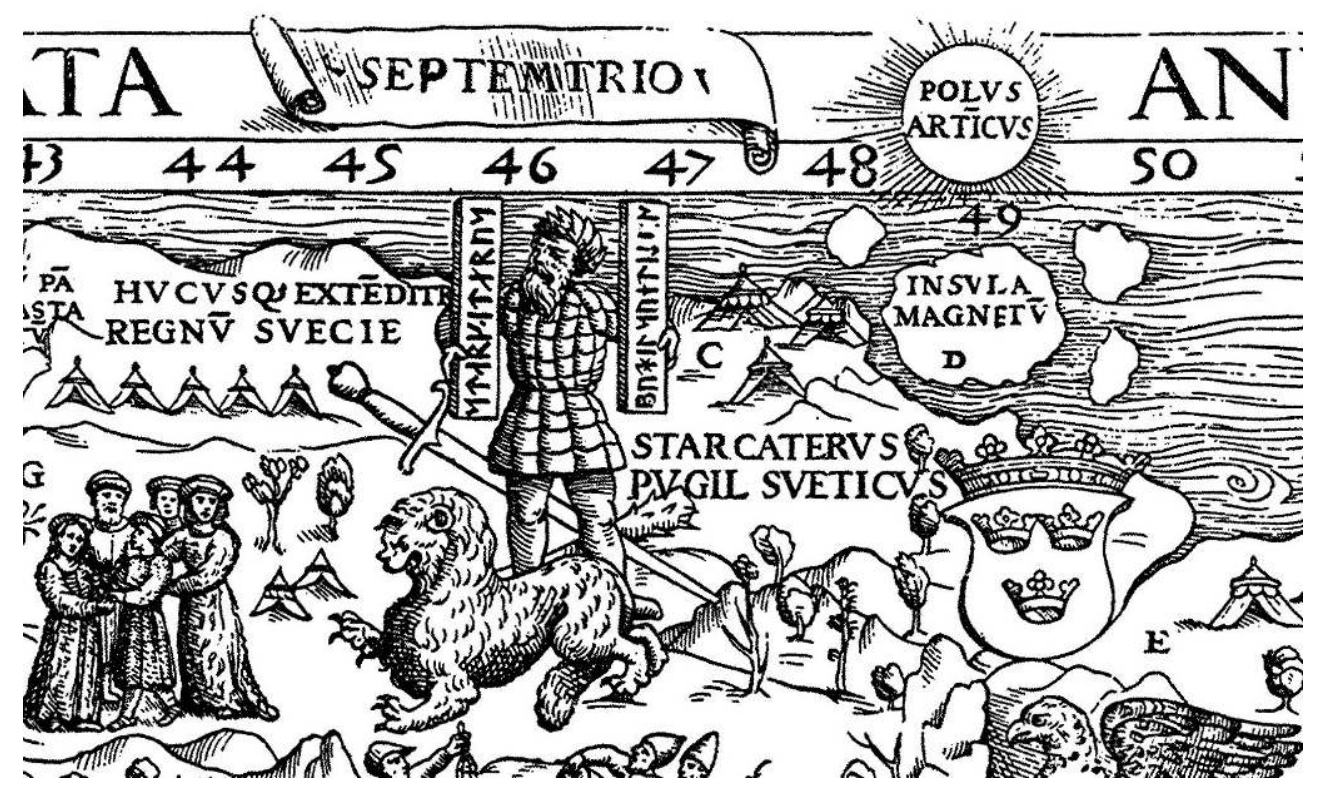

\section{About the two originals}

31 One of the open questions concerning the Carta marina is that unfortunately it has not been possible to explain how a large map, and even all its nine separate leaves, could have disappeared in the 1570 s so totally that it was not until in 1886 when the first example was found. It was rolled-up among the Scandinavian maps at the then Hofund Staatbibliothek in Munich. It is also a wonder how more than 30 years could pass after 1962 - the year of the discovery of the Uppsala University Library example before it was discovered that there is more than only one difference (Richter 1967,38; Sallander 1962, 132) between the two copies (figure 12a). In addition to some minor 
differences there is one important difference in the Munich and Uppsala copies in that they were directed to different recipients. (Miekkavaara 2007, 305-306). This can be seen from the Latin commentaries on the maps, on the first line in the chapter where Olaus Magnus greets his well-disposed reader. On the Uppsala copy he states that the map of the northern countries was published in honour of the most serene Doge Pietro Lando and the Council of Venice and for the general benefit of the Christian world (qua ad laude serenissime Ducis Petri Landi Senatusq3 Venet. ac publicam christiani orbis vtilitate emitto) (figure. 12b). The text on the Munich copy says that the map was published in honour of the celebrated Germanic and Gothic nations and for the general benefit of the Christian world [quam ad laudem inclite Germanice et Gothice nationis ac publicam christiani orbis vtilitate emitto]. It is interesting to notice that the commentaries of the Carta marina were directed to almost the same recipients. The Italian Opera breve was dedicated to the Council of Venice and Doge Pietro Lando. The German Ain kurze Auslegung was dedicated to the Royal town of Danzig in Prussia, and Olaus Magnus also expressed greetings to its Mayor, Council and Burghess. He wanted to thank the parties concerned in Venice and Danzig for the kindness and hospitality they had offered to him and his brother.

32 It is obvious that Olaus Magnus had produced two versions of his map which he had planned to circulate in different parts of Europe together with their vernacular commentaries, but the more clear outward appearance of the Uppsala copy with different parentheses and type-setting of the text leads to questions to which the answer "the Uppsala copy is in a much better condition than that in Munich" is not enough.

Figure 12a. For a long time, the missing name of Saxo from the Munich copy of the Carta marina has been considered to be the only difference between the two known copies.

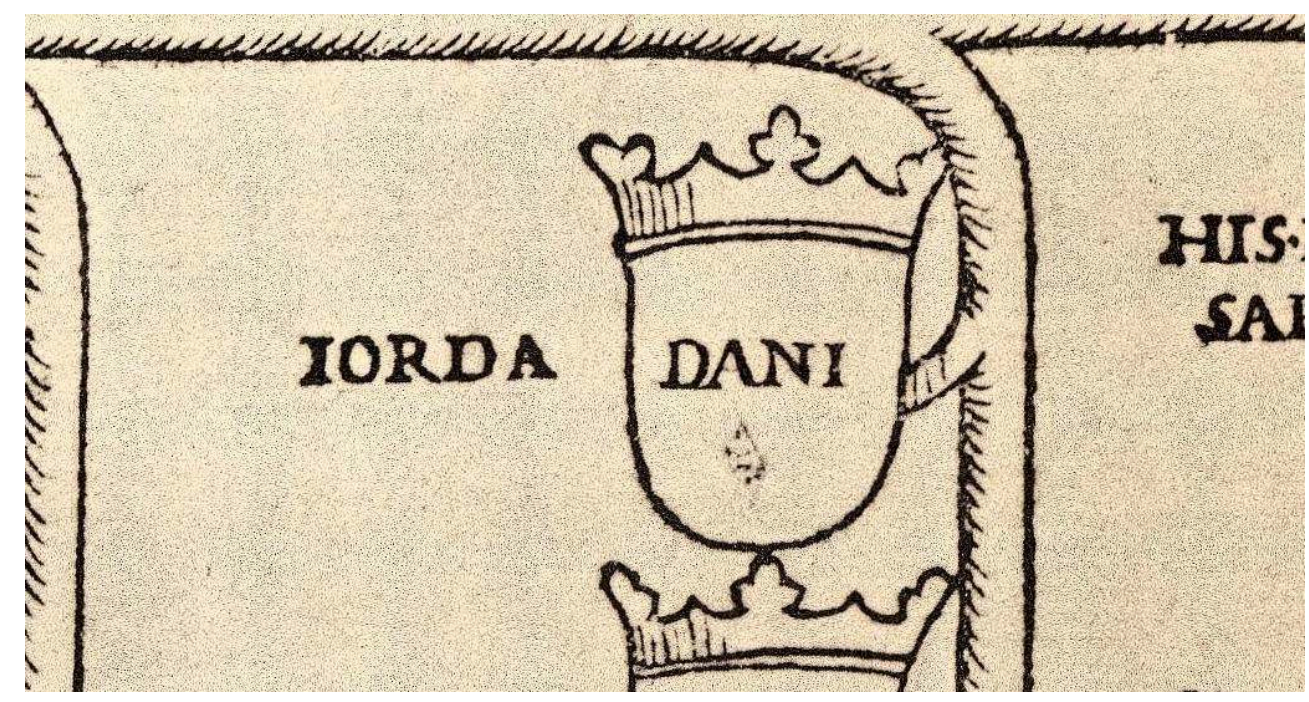




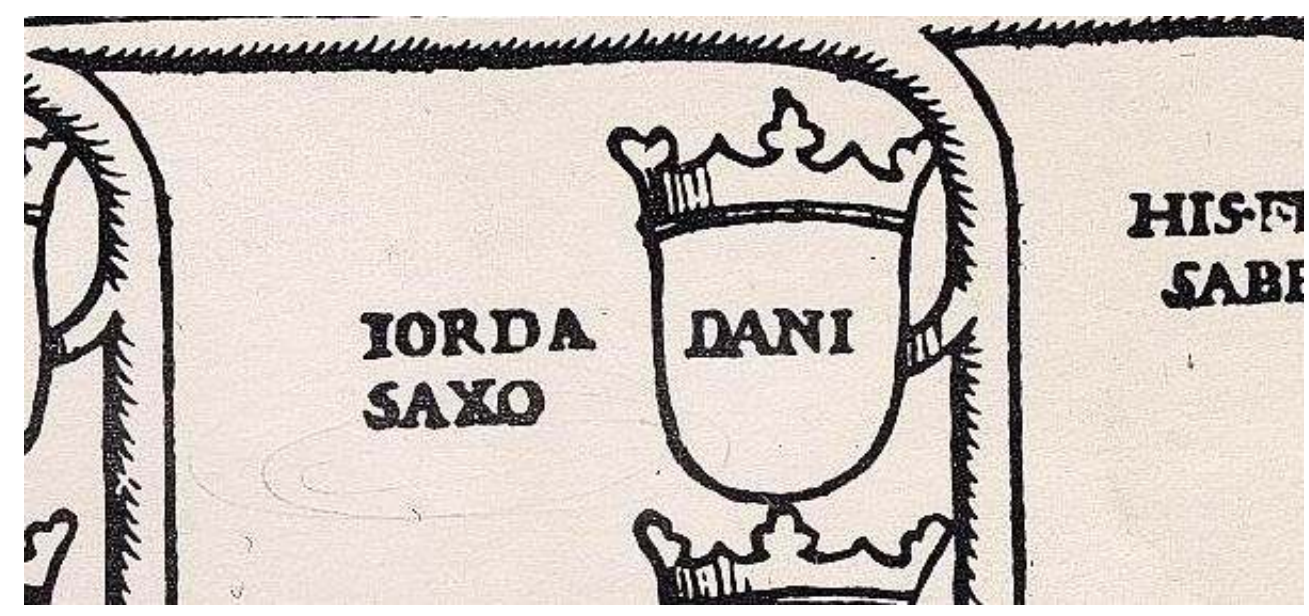

Figure 12b. The extracts of the Latin commentaries on the Munich and Uppsala copies prove that the maps had been directed to different recipients.

Olaws Magnus Cosbus beni gno le'tori Jalutem.

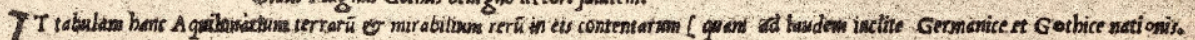

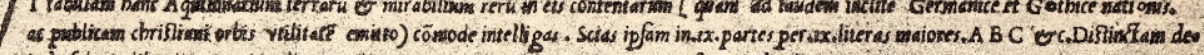

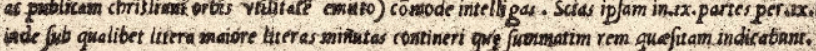

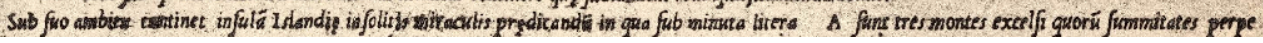

a - Olaus Magnus Gothus kemigno lestori Jalutem.

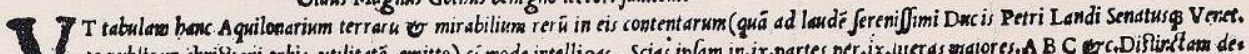

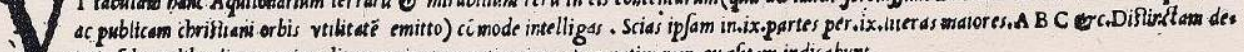
W. inde fub qualibet litera maiore literas minutas contineri qug jummutim rem quefitam indicabunt.

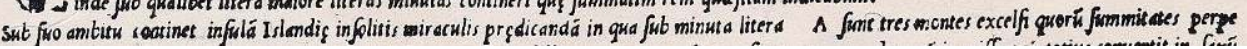

\section{Summa summarum}

33 A lot of research and even new source materials are needed to solve still open questions, but even if they remain unresolved, it does not reduce the value of the Carta marina. It was one of the most remarkable maps of its time. A large part of Europe, including the whole Scandinavia with its surroundings, was mapped better than ever before. The Carta marina became a model for many notable cartographers and the basis for describing the Northern countries on the map for nearly 100 years.

\section{BIBLIOGRAPHY}

AHLENIUS K. (1895), Olaus Magnus och hans framställning af Nordens geograpfi: studier i geografins historia, Akademisk afhandling, Uppsala, Uppsala Univ.

BALZAMO E. (2005), Carta Marina 1539, Collection Merveilleux n²6, Paris, Librarie José Corti.

BRATT E. (1953), “Olaus Magnus historia till svenska: en vitter bragd”, Ymer, 73, 4, pp. 266-275, Stockholm, Svenska sällskapet för antropologi och geografi.

CRONE G.R. (1950), ["Reply to J. Granlund"], Imago Mundi A Review of Early Cartography, 8, 43, Stockholm, E.J.Brill. 
CRONE G.R. \& GEORGE F. (1949), “Olaus Magnus and his Carta marina:A problem in sixteenthcentury cartography”, The Geographical Journal 114, pp. 197-200, London, Royal Geographical Society.

CRONE G.R. \& GEORGE F. (1952), “A Note on Olaus Magnus' Map”, Imago Mundi A Review of Early Cartography, 9, 82, Stockholm, E.J.Brill.

EHRENSVÄRD U. (2006), The history of the Nordic map from myths to reality, Helsinki, John Nurminen Foundation.

FOOTE P. (1996), Introduction, Olaus Magnus, Description of the northern peoples, Rome 1555= Historia de gentibus septentrionalibus, Romae 1555, translated by Peter Fisher and Humphrey Higgens, edited by Peter Foote, Volume 1, Second series no. 182, London, Hakluyt Society.

GINSBERG W.B. (2006), Printed Maps of Scandinavia and the Arctic 1482-1601, New York, Septentrionalium Press.

GRANLUND J. (1946), Syn och sanning hos Olaus Magnus, Fataburen,1946, 119-132, Stockholm, Nordiska Museet.

GRANLUND J. (1950), “The Carta Marina of Olaus Magnus”, Imago Mundi A Review of Early Cartography, 8, 35-43, Stockholm, E.J.Brill.

GRANLUND J. (1951), Efterskrift, Olaus Magnus, Historia om de nordiska folken, 5, Kommentar, Uppsala, Michaelisgillet.

GRANLUND J. (1952), “A Note on Olaus Magnus' Map”, Imago Mundi A Review of Early Cartography, 9, 82, Stockholm, E.J.Brill.

GRAPE Hj. (1970), Olaus Magnus - forskare, moralist, konstnär, Stockholm, Proprius förlag.

KARROW R. (1993), Mapmakers of the sixteenth century and their maps, bio-bibliographies of the cartographers of Abraham Ortelius 1570, Winnetka, Ill., Speculum Orbis Press.

LYNAM E. (1949), The Carta marina of Olaus Magnus, Venice 1539 \& Rome 1572, Tall Tree Library Publications 12, Jenkintown, Pa, Tall Tree Library.

MAGNUS Olaus (1539/1887), Opera breve, la quale demonstra, e dechiara, ouero da il modo facile de intendere la charta, ouer del le terre frigidissime di Settentrione : oltra il mare Germanico, doue si contengono le cose mirabilissime de guelli paesi, fin'a quest'hora non cognosciute, ne da Greci, ne da Latini, Venetia MDXXXIX, Fotografiskt facsimile utfördt vid Generalstabens Litogrfiska Anstalt efter ett original tillhörigt Eriksbergs Arkiv i Södermanland, Stockholm.

MAGNUS Olaus (1539/1912), Ain kurze Auslegung vnd Verklerung der neuuen Mappen von den alten Goettenreich vnd andern Nordlenden Venedig 1539, Faksimile med inledning utg. af Isak Collijn, Stockholm, Cederquists grafiska aktiebolag.

MAGNUS Olaus (1539/1993), Carta marina et descriptio septemtrionalium terrarum ac mirabilium rerum in eis contentarum diligentissime elaborata anno dni 1539 Venetiis..., Pienennetty näköispainos Uppsalan yliopiston kirjastossa olevasta alkuperäiskartasta, Helsinki, Karttakeskus.

MIEKKAVAARA L. \& KOISTINEN P. (1993), Johdanto, Olaus Magnus Gothus, Carta marina ja sen selitys 1539, Helsinki, Karttakeskus.

MIEKKAVAARA L. (1994), Carta marina, the visualization of the northern countries, Nordic summer course in cartography: visualization of geographical data 4-11 June 1994, Espoo, 6-11, Helsinki, Helsinki University Press.

MIEKKAVAARA L. (2007), Which is which? Which is where? How to identify the two original copies of Olaus Magnus' Carta marina of 1539, Mappae Antiquae Liber Amicorum Günter Schilder, 
Vriendenboek ter gelegenheid van zijn $65^{\text {ste }}$ verjaardag, Essays on the occasion of his $65^{\text {th }}$ birthday... Edited by Paula van Gestel-van het Schip and Peter van der Krogt..., 't Goy-Houten, Hes \& De Graaf, pp. 297-307.

RICHTER H. (1939), “Olaus Magnus och hans Carta marina 1539 Ett fyrahundraårsminne”, Ymer, 59, pp. 97-112, Stockholm, Svenska sällskapet för antropologi och geografi.

RICHTER H. (1967), “Olaus Magnus Carta marina 1539”, Lychnos-bibliotek 11, 2, Lund, Lärdoms historiska samfundet.

SALLANDER H. (1962), “Olaus Magnus' Carta marina av år 1539, Några anteckningar i samband med ett nyupptäckt andra exemplar”, Nordisk Tidskrift för Bok- och Biblioteksväsen 49, pp. 129-135, Uppsala, Almqvist \& Wiksell.

\section{NOTES}

1. For the life of Olaus Magnus see e.g. AHLENIUS K., 1895, pp. 37-58; FOOTE P., 1996, XXvi-Xxxvi; GRANLUND J., 1951, pp.561-581; GRAPE Hj., 1970, pp.11-84, 234-239; KARROW R., 1993, pp. 362-366; RIHTER H., 1967, pp. 9-36.

2. Terrarvm Septentrionalium Exacta Novissimaqve descriptio per Livinvm Algoet et alijs autoribus 1562. Antverpie apud Gerardum de Juede supra borsam nouam. (Only copy known at Bibliothèque nationale, Paris). In 1570 de Jode published a reduced copy of Algoet's map Septentrionalium regionvm Svetice Gothice Norvegice Danice et terrarum adiacentium recens exactaque descriptio per Liuinum Algoet Auctorem Gerardum de Iode excudebat. Both maps have been published in GINSBERG W.B. (2006), pp. 86-87 and 122, resp.

\section{ABSTRACTS}

Olaus Magnus, a highly educated Swedish priest and scholar, published his geographically and ethnographically remarkable map of the Northern countries, the Carta marina, in Venice in 1539. During his travels in southern and central Europe Olaus Magnus had noticed how little people knew about the northern regions. Through the map he wanted to remove this obscurity.

The map - which was one of the largest maps of its time (woodcut, $125 \times 170 \mathrm{~cm}$ ) - changed the cartographic representation of the Northern countries profoundly for nearly a hundred years. Due to its numerous illustrations and commentaries, the map was and is a fascinating description of the life in the region during the sixteenth century.

The Carta marina was accepted, and it became a model for many cartographers in depicting the Northern countries. Even today the map fascinates the scholars, and many questions are still left unsolved.

Olaus Magnus, un prêtre et lettré suédois, avait une très bonne éducation. C'était à Venise en 1539 qu'il a publié la Carta Marina, sa carte des pays nordiques, une oeuvre remarquable géographiquement et ethnographiquement. Au cours de ses voyages en Europe méridionale et centrale Olaus Magnus avait remarqué combien les gens avaient d'infimes connaissances des régions du Nord. Il a voulu écarter cette obscurité par l'intermédiaire de la carte. 
La carte qui était une des plus grandes de son temps (gravure sur bois, $125 \times 170 \mathrm{~cm}$ ) a changé profondément la représentation cartographique des pays nordiques. C'est à cause de ses nombreuses illustrations et commentaires que la carte a fait une description fascinante de la vie dans la région au seizième siècle.

La Carta Marina a été acceptée, et, pendant presque une centaine d'années elle a servi de modèle de représentation des pays nordiques pour nombre de cartographes. Même aujourd'hui, la carte fascine les chercheurs, et, beaucoup de questions attendent encore une réponse.

\section{INDEX}

Mots-clés: cartographie, cartes historiques, histoire, pays scandinaves, Olaus Magnus, Carta marina 1539

Keywords: cartography, historical maps, history, Scandinavian countries, Olaus Magnus, Carta marina 1539

\section{AUTHOR}

\section{LEENA MIEKKAVAARA}

Pyörrekuja 12, 04300 Tuusula, Finland, leena@miekkavaara.com 